\title{
Penggunaan Darah sebagai Biomarker Paparan Logam Cadmium Masyarakat Pesisir Sungai Musi (Efek terhadap Eritrosit dan Leukosit)
}

\author{
Pra Dian Mariadi ${ }^{1}$, Ian Kurniawan ${ }^{1 *}$, Theresia Anita ${ }^{2}$, Berti Betrandas Rosari Ngole ${ }^{3 *}$ \\ e-mail: iankurniawan@ukmc.ac.id \\ ${ }^{1}$ Prodi Diploma IV Teknologi Laboratorium Medik Universitas Katolik Musi Charitas \\ ${ }^{2}$ Prodi III Kebidanan Universitas Katolik Musi Charitas \\ ${ }^{3}$ Alumni DIV Teknologi Laboratorium Medis Universitas Katolik Musi Charitas
}

\begin{abstract}
The content of heavy metals of cadmium in the blood of people used Musi River water for daily needs has higher potential for contamination than live in urban areas. This study was analyze the levels of cadmium in the blood as biomarker of metal pollution and to see its effect on the number of erythrocytes and leukocytes. Research is analytic observational. The population in this study were the mothers of 7 Ulu Kampung Kapitan Laut, Seberang Hulu 1 District, Palembang City. Sampling was done by purposive sampling method. Sample examination was carried out at the Palembang Health Laboratory Center. The results showed that there were 3 samples that contained Cadmium in their blood with varying level between 0.3 to $1.1 \mathrm{mg} / \mathrm{L}$. The level of cadmium in the blood is still relatively safe for humans, but the presence of the metal has a chronic effect on human health when used for daily activities continuously. Cadmium affects blood components, namely erythrocytes and leukocytes in the body because increased protoporphirin in red blood cells (erythrocytes) which causes a decrease in the number of red blood cells and triggers anemia. Heavy metals also trigger changes in the structure and number of leukocytes, especially monocytes.
\end{abstract}

Keywords: Heavy metals, Cadmium, Erythrocytes, Leukocytes

\begin{abstract}
ABSTRAK
Kandungan logam berat berupa cadmium dan timbal dalam darah pada orang yang memanfaatkan air Sungai Musi untuk kebutuhan sehari-hari memiliki potensi terkontaminasi lebih tinggi daripada orang yang tinggal di perkotaan. Penelitian ini untuk menganalisis kadar kadmium dalam darah sebagai biomarker pencemaran logam serta melihat efeknya terhadap jumlah eritrosit dan leukosit. Penelitian yang bersifat observasional analitik. Populasi dalam penelitian ini adalah ibu-ibu 7 Ulu Kampung Kapitan Laut RT 52, Kecamatan Seberang Hulu 1 Kodya Palembang. Pengambilan sampel dilakukan dengan metode purposive sampling. Pemeriksaan sampel dilakukan di Balai Besar laboratorium Kesehatan Palembang. Hasil penelitian menunjukkan terdapat 3 sampel yang di dalam darahnya mengandung logam berat dengan kadar yang bervariasi antara $0,3 \mathrm{s.d} 1,1 \mathrm{mg} / \mathrm{L}$. Kadar cadmium dalam darah masih relatif aman untuk manusia, akan tetapi keberadaan logam berat berpengaruh secara kronis terhadap kesehatan manusia apabila di gunakan untuk kegiatan seharihari selama terus menerus. Cadmium berpengaruh terhadap komponen darah yaitu eritrosit dan leukosit didalam tubuh karena logam berat dapat meningkatkan protoporphirin dalam sel darah merah (eritrosit) yang menyebabkan penurunan jumlah sel darah merah dan memicu terjadinya anemia . Logam berat juga memicu perubahan struktur dan jumlah leukosit terutama monosit.
\end{abstract}

Kata Kunci: Logam Berat, Cadmium, Eritrosit, Leukosit 


\section{PENDAHULUAN}

Logam berat seperti cadmium dan timbal merupakan logam berat yang sangat berbahaya bagi kesehatan. Kedua logam ini terdapat secara alami di lingkungan, akan tetapi jumlahnya dapat meningkat akibat pembuangan dan pemakaian baterai, kegiatan industri, keramik, penggunaan pupuk phosphate, batubara, bahan bakar dan industri pewarna (Andjelkovic et al, 2019; Bassil et al, 2017). Pemeriksaan dan pencegahan terpapar logam cadmium menjadi isu utama masyarakat luas walaupun kadar terpaparnya rendah dalam tubuh karena efek toksisitasnya yang tinggi. (Jarup, 2003). Logam cadmium dapat terakumulasi daam tubuh melalui rantai makanan dan merokok dikarenakan logam ini dapat diserap tanaman dan sayuran dari dalam tanah. (Vacchi-Suzzi et al, 2015) dan (Lin, 2021).

$$
\text { Logam kadmium dapat }
$$

terakumulasi dan disimpan dalam berbagai organ dalam tubuh seperti ginjal dan hati (jarup and akesson, 2009) serta dapat menyebabkan berbagai gangguan kesehatan termasuk resiko tinggi kaknker, disfungsi ginjal/penyakit ginjal akut, penyakit saluran pernapasan dan jantung ( Hecht et al, 2016; Madrigal et al, 2019; Wang et al 2021). Logam berat juga dapat berefek pada jumlah eritrosit karena dapat meningkatkan protoporphirin dalam sel darah merah (eritrosit) yang menyebabkan penurunan jumlah sel darah merah dan memicu terjadinya anemia (Juliana et al, 2017). Menurut Soleman et al tahun 2020, logam berat juga memicu perubahan struktur dan jumlah leukosit terutama monosit. Penelitian lain menunjukkan terdapat hubungan antara logam $\mathrm{Cd}$ terhadap miRNA-21 di tubuh dan jaringan pasien yang menderita kangker kandung kemih (Awadalla, et al, 2020, Wang et al, 2021).
Logam kadmium dapat masuk dalam tubuh dan terakumulasi dalam mahluk hidup. Paparan logam kadmium dalam tubuh diakibatkan dari kebiasaan merokok (Chao et al, 2014) dan mengkonsumsi makanan yang mengandung logam berat kadmium ( garner and levallois, 2016; Kiyaeva and Notova, 2019). Beberapa penelitian menunjukkan bahwa makanan ini berasal dari tanaman pangan yang ditumbuhkan dari tanah dan air yang sudah tercemar logam (Rizwan et al, 2017) atau makanan lain yang tercemar logam kadmium seperti anas moschata dan Cairina moschata (Mariadi et al, 2018), Ikan Gabus (Channa Sriata) (Mariadi dan Kurniawan, 2019), Channa striata dan Mystus (Amallia, Wijaya dan Dhani 2020). Selain melalui makanan masuknya logam berat dapat melalui, minuman, udara (proses pernapasan) serta perembesan atau penitrasi pada selaput atau lapisan kulit dari air yang mengandung logam berat. (Suciani, 2007). Salah satu sumber air yang masih digunakan bagi masyarakat kota Palembang adalah sungai musi dimana menurut beberapa laporan sungai ini sudah tercemar beberapa logam berat seperti kadmium.

Biomonitoring paparan logam cadmium dalam tubuh awalnya menggunakan kadar cadmium dalam urine, akan tetapi saat ini sudah menggunakan kadar cadmium dalam darah (Vacchi-suzzi et al, 2016). Standar deviasi (SD) yang didapat dari 43 laboratorium yang tergabung dalam proyek HBM-4EU Eropa menunjukkan nilai SD sebesar $8-36 \%$ untuk pemeriksaan $\mathrm{Cd}$ dalam urine dan $8-28$ $\%$ untuk pemeriksaan $\mathrm{Cd}$ dalam darah yang dianalisa menggunakan inductivelycouple plasma mass spectrometry (ICPMS) (Nubler et al, 2021). Penelitian ini mengukur kadar logam cadmium dalam 
darah ibu-ibu yang berdomisili di pinggiran sungai musi yang kesehariannya masih menggunakan air sungai musi untuk kebutuhan sehari hari .

\section{BAHAN DAN METODE}

\section{Jenis Penelitian}

Jenis penelitian ini merupakan penelitian observasional analitik atau bisa juga disebut penelitian epidemiologi atau penelitian survey. Penelitian obeservasional adalah suatu penelitian yang melakukan kajian terhadap persoalan kesehatan dengan menggunakan pendekatan komunitas atau kelompok sosial. Peneliti tidak melakukan suatu tindakan manipulasi terhadap variabel yang diteliti (Siswanto et al, 2014). Rancangan penelitian pada penelitian ini adalah Cross Sectional. Rancangan penelitian tersebut bermaksud untuk mempelajari antara faktor resiko dengan timbulnya efek (Notoatmojo, 2018).

\section{Laboratorium Pemeriksaan}

Pemeriksaan sampel dilakukan di laboratorium pemeriksaan yang memiliki kompetensi (akeditasi) dan instrumentasi yang digunakan tersedia. Pemeriksaan kadar cadmium dalam darah dilakukan di laboratorium Prodia Palembang sedangkan pemeriksaan kadar leukosit dan eritrosit dilakukan di Balai Besar Laboratorium Kesehatan (BBLK) Palembang.

\section{Sampel dan Lokasi Penelitian}

Populasi dalam penelitian ini adalah ibuibu 7 Ulu Kampung Kapitan Laut RT 52, Kecamatan Seberang Hulu 1 Kodya Palembang. Cara pengambilan sampel dilakukan dengan metode purposive sampling yaitu sebanyak 17 orang ibuibu, tetapi yang bersedia diambil darahnya sebanyak 3 orang. Ibu-ibu tersebut masih menggunakan air sungai untuk kegiatan sehari hari seperti mandi, menyikat gigi, mencuci pakaian, mencuci alat-alat makan, memasak dan sebagainya.

\section{Waktu Penelitian}

Penelitian akan dilakukan dalam dalam jangka waktu \pm 2 bulan pada bulan Agustus - September 2021.

\section{Prosedur Penelitian}

a. Pengambilan Darah (Permenkes No.43 (2013)

1) Pakai APD lengkap

2) Identifikasi pasien

3) Subjek diminta untuk duduk dengan posisi lengan lurus dan pilih vena

4) Pilih bagian vena mediana cubiti dan raba untuk memastikan posisi vena

5) Pasang tourniquet pada lengan

6) Bersihkan kulit pada bagian vena yang akan diambil darah dengan kapas alcohol 70\% lalu biarkan kering.

7) Tusuk bagian vena dengan spuit, posisikan lubang jarum $30-45$ derajat, lalu hisap darah hingga volume darah cukup.

8) Sampel ditampung dalam tabung lalu beri identitas dank ode

9) Letakkan kapas alkohol pada bekas tusukan lalu tarik jarum keluar

10) Tekan kapas pada bagian tersebut lalu plester bagian tersebut

11) Buang jarum bekas ambil darah kedalam wadah pembuangan benda tajam.

\section{b. Pemeriksaan Cd dalam Darah}

1) $2 \mathrm{ml}$ sampel darah dipersiapkan sebelum analisis, masukkan sampel ke dalam tabung reaksi

2) Tambahkan $5 \mathrm{ml} \mathrm{HNO}_{3}$ pekat melalui dinding tabung

3) Destruksi sampel tabung reaksi dengan cara masukkan ke dalam beker gelas lalu masukkan ke dalam alat novawave. 
4) Dinginkan hasil destruksi lalu saring, setelah itu dimasukkan ke dalam labu ukur $10 \mathrm{ml}$, dan tambahkan dengan aquabides sampai tanda batas pada tabung.

5) Baca pada alat Inductively Coupled Plasma (ICP)

c. Pemeriksaan Eritrosit dan Leukosit

1) Hidupkan komputer, printer dan instrumen sysmex XS-800i pada tombol sebelah kiri alat.

1) Lakukan pengecekan status alat, pastikan dalam keadaan Ready (lampu Ready menyala hijau)

2) Siapkan sampel pasien, minimal 500 $\mu l$ darah EDTA

3) Kemudian klik Manual, masukkan nomor sampel (maksimal 15 digit), pilih discrete $(\mathrm{CBC}$ atau $\mathrm{CBC}+$ DIFF) dan pilih No pada Capillary mode. Patient ID boleh diisi atau tidak diisi

4) Klik OK setelah selesai diset.

5) Campur sampel kemudian buka penutup sampel, masukkan tabung yang talah berisi darah ke dalam aspiration port kemudian tekan tombol start.

6) Lampu hijau akan berkedip-kedip dan tunggu hingga terdengar beep $2 \mathrm{x}$ lalu tarik sampel.

7) Lakukan pencetakan hasil dengan cara pilih data yang akan dicetak kemudian klik report, lalu hasil akan keluar secara otomatis.

\section{HASIL DAN PEMBAHASAN}

Cadmium (Cd) adalah logam yang bersifat karsinogetik yang tergolong ke dalam logam pencemaran udara. Namun, menurut Nordberg et al tahun 2015 menyatakan bahwa pencemaran logam cadmium ditemukan dalam air sungai Jinzu, dan anak sungainya. Cadmium juga banyak di temui di dalam darah, walaupun konsentrasinya kecil tetap berbahaya bagi manusia.
Potensi masuknya $\mathrm{Cd}$ dalam darah melalui interaksi langsung air sungai musi yang telah tercemar. Konsentrasi $\mathrm{Cd}$ di dalam air sungai musi tercatat pada tahun 2018 yaitu $0,003 \mathrm{mg} / \mathrm{L}$ pada bulan Maret, $\quad 0,004 \mathrm{mg} / \mathrm{L}$ pada bulan September, dan $0,003 \mathrm{mg} / \mathrm{L}$ pada bulan November dengan ambang batas 0,1 $\mathrm{mg} / \mathrm{L}$. menurut Permenkes (2017) batas maksimum cadmium untuk keperluan higiene sanitasi adalah 0,005 $\mathrm{mg} / \mathrm{L}$. Berdasarkan data tersebut, dapat dilihat kadar cadmium di dalam air sungai musi masih tergolong rendah. Kadar cadmium yang rendah sekalipun di dalam air sungai juga berpengaruh terhadap kesehatan manusia apabila digunakan untuk kegiatan sehari-hari selama terus menerus.

Paparan Cadmium terhadap manusia dapat diukur dengan biomarker yang terdapat di dalam urine dan darah. Kadmium di dalam darah menunjukkan recent esposure sedangkan cadmium yang terdapat didalam urin menunjukkan total beban logam (ATSDR, 2012) dalam (Dewi, 2020). Paparan cadmium menimbulkan beberapa gangguan kesehatan. paparan akut cadmium yang melalui jalur pernapasan terjadi 4-10 jam setelah terpapar dapat menimbulkan gejala seperti dispna, batuk, dada terasa sesak, edema paru, dll. Sedangkan paparan kronis dapat menimbukan gangguan ginjal, gangguan kardiovaskuler dan kanker. Pada penelitian yang dilakukan oleh Dewi, (2020) menyebabkan meningkatnya tekanan darah sistolik dan diastolik yang berpengaruh pada kejadian hipertensi.

Dewi (2020) menyatakan Partikel Cadmium (Cd) dapat menempel pada tangan pekerja yang memungkinkan masuk ke dalam tubuh pekerja melalui jalur ingetsi. Penelitian ini dilakukan pada responden yang masih menggunakan air sungai musi untuk keperluan sehari-hari. Kegiatan seharihari yang biasa mereka lakukan adalah 
mencuci, mandi, BAB menggunakan air sungai musi. Hal ini terjadinya interaksi antara tubuh atau kulit seseorang dengan air sungai musi yang memungkinkan responden terpapar logam berat Cd. Hasil penelitian terkait kadar cadmium dan analit darah lainnya dapat dilihat dalam tabel 1 .

Tabel 1. Hasil Penelitian

\begin{tabular}{|l|l|l|l|}
\hline No & $\begin{array}{l}\text { Kadar } \\
\text { cadmium } \\
(\mu \mathrm{g} / \mathrm{L})^{*}\end{array}$ & $\begin{array}{l}\text { Jumlah } \\
\text { eritrosit } \\
(\text { dalam } \\
\left.10^{6} / \mu \mathrm{l}\right)\end{array}$ & $\begin{array}{l}\text { Jumlah } \\
\text { leukosit } \\
(\text { dalam } \\
\left.10^{3} / \mu \mathrm{l}\right)\end{array}$ \\
\hline 1 & 1.1 & 5.09 & 5.7 \\
\hline 2 & 1.1 & 4.09 & 6.8 \\
\hline 3 & 0.3 & 4.96 & 12.5 \\
\hline
\end{tabular}

Verifikasi metode untuk pemeriksaan eritrosit dan leukosit menggunakan bahan kontrol normal yang dilakukan dengan cara melakukan pemeriksaan bahan kontrol normal sebanyak 20 kali pengulangan. Data pemeriksaan bahan kontrol yang telah dilakukan sebanyak 20 kali digunakan untuk melakukan perhitungan presisi, akurasi, dan TEa (Total Allowable Error). Hasil verifikasi pemeriksaan jumlah eritrosit diperoleh hasil uji presisi $1,13 \%$ dengan nilai maksimum $4 \%$, hasil uji akurasi $0,12 \%$ dengan nilai maksimum $6 \%$ dan nilai TEa 2,3\% dengan nilai maksimum 20\%. Maka dapat disimpulkan bahwa metode pemeriksaan masih dalam batas keberterimaan karena kurang dari nilai maksimum sehingga dapat dilanjutkan untuk pemeriksaan terhadap sampel

Verifikasi metode pemeriksaan jumlah leukosit diperoleh hasil uji presisi $3.43 \%$ dengan nilai maksimum $7.0 \%$, hasil uji akurasi $1.85 \%$ dengan nilai maksimum $15 \%$ dan nilai TEa $6.45 \%$ dengan nilai maksimum 20\%. Maka disimpulkan bahwa metode pemeriksaan leukosit masih dalam batas keterimaan karena kurang dari nilai maksimum, sehingga dapat dilanjutkan untuk pemeriksaan terhadap sampel.

Pada penelitian ini kadar cadmium dari 3 responden masih dalam batas normal dengan hasil rata-rata $0.83 \mu \mathrm{g} / \mathrm{L}$ dengan nilai normal $<4,9 \mu \mathrm{g} / \mathrm{L}$. Hal ini menunjukkan bahwa kadar cadmium dalam darah sampel uji tidak melebihi ambang batas dan relatif aman di dalam tubuh. Akan tetapi, hal ini tetap harus menjadi perhatian karena Cadmium berpengaruh terhadap komponen darah yaitu eritrosit dan leukosit didalam tubuh. Juliana et al (2017) menyatakan logam berat dapat meningkatkan protoporphirin dalam sel darah merah (eritrosit) yang menyebabkan penurunan jumlah sel darah merah dan memicu terjadinya anemia sedangkan menurut Soleman et al (2020) logam berat juga memicu perubahan struktur dan jumlah leukosit terutama monosit.

Hasil penelitian ini menunjukkan kadar cadmium yang rendah pada sampel darah sehingga tidak mempengaruhi jumlah eritrosit dan jumlah leukosit dengan rata rata jumlah eritrosit dan leukosit berturut-turut $4,71 \times 10^{6} / \mu 1$ dan $8,310^{3} / \mu 1$ yang tergolong normal. Hal ini berbeda dengan hasil penelitian Juliana et al (2017) dan Soleman et al (2020) yang menunjukkan pada kelompok responden yang memiliki kadar logam berat melebihi ambang batas akan mempengaruhi jumlah eritrosit dan leuksit. Rendahnya paparan logam cadmium dalam darah juga diduga karena proses masuknya logam melalui kulit dari kegiatan rumah tangga sehari-hari seperti mencuci dan mandi.

\section{KESIMPULAN}

Penduduk di lokasi penelitian pesisir Sungai Musi telah terpapar oleh salah satu logam berat Cadmium (Cd). Penggunaan air Sungai Musi untuk dikonsumsi perlu dikurangi untuk 
mengatasi dampak jangka panjang dari Logam berat terhadap kesehatan manusia.

\section{UCAPAN TERIMA KASIH}

Penelitian ini disponsori oleh Lembaga Penelitian dan Pengabdian Masyarakat Universitas Katolik Musi Charitas Palembang.

\section{DAFTAR PUSTAKA}

Amallia, RA., Wijaya, K.S., Dhani, A.B. (2020). Analysis Of Lead Level In Fish As a Water Bioindicator. Sainmatika: Jurnal Ilmiah Matematika dan Ilmu Pengetahuan Alam. Volume 17 Nomor 2, Desember 2020. DOI 10.31851/sainmatika.v17i2.5053

Andjelkovic, M., Buha Djordjevic, A., Antonijevic, E., Antonijevic, B., Stanic, M., Kotur-Stevuljevic, J., Spasojevic-Kalimanovska, V., Jovanovic, M., Boricic, N., Wallace, D., \& Bulat, Z. (2019). Toxic Effect of Acute Cadmium and Lead Exposure in Rat Blood, Liver, and Kidney. International journal of environmental research and public health, 16(2), 274. https://doi.org/10.3390/ijerph16020 $\underline{274}$

Awadalla, A., Mortada, W. I., Abol-Enein, H., \& Shokeir, A. A. (2020). Correlation between blood levels of cadmium and lead and the expression of microRNA-21 in Egyptian bladder cancer patients. Heliyon, 6(12), e e 05642. https://doi.org/10.1016/j.heliyon.20 20.e05642

Bassil, M., Daou, F., Hassan, H., Yamani, O., Kharma, J. A., Attieh, Z., \& Elaridi, J. (2018). Lead, cadmium and arsenic in human milk and their socio-demographic and lifestyle determinants in Lebanon. Chemosphere, 191, 911921.

https://doi.org/10.1016/j.chemosphe re.2017.10.111
BLH. (2020). Data Kadar Logam Berat Pada Sungai Musi Kota Palembang.

Dewi, C.H. 2020. Perbedaan kadar cadmium (Cd) dalam darah dan tekanan darah pada pengelas dan non pengelas di PT X Surabaya. Jurnal Wiyata. P-ISSN 2355-6498, EISSN 2442-6555

Garner, R., \& Levallois, P. (2016). Cadmium levels and sources of exposure among Canadian adults (pp. 10-8). Statistics Canada

Järup L. (2003). Hazards of heavy metal contamination. British medical bulletin, 68, 167-182. https://doi.org/10.1093/bmb/ldg032

Järup, L., \& Akesson, A. (2009). Current status of cadmium as an environmental health problem. Toxicology and applied pharmacology, 238(3), 201-208. https://doi.org/10.1016/j.taap.2009. $\underline{04.020}$

Juliana, C., Nurjazuli, N., \& Suhartono, S. (2017). Hubungan Kadar Timbal dalam Darah dengan Jumlah Eritrosit, MCV dan MCH Pada Ibu Hamil di Daerah Pantai. HIGIENE: Jurnal Lingkungan, 3(3), 161-168 Kesehatan

Kiyaeva, E. V., \& Notova, S. V. (2019, October). Influence of cadmium on blood and hair trace elements and biochemical markers. In $I O P$ Conference Series: Earth and Environmental Science (Vol. 341, No. 1, p. 012174). IOP Publishing.

Hai-Hsuan Chao, Chih-Hung Guo, ChungBin Huang, Pei-Chung Chen, HsiuChuan Li, Der-Yun Hsiung, YuKung Chou. (2014). Arsenic, Cadmium, Lead, and Aluminium Concentrations in Human Milk at Early Stages of Lactation. Pediatrics \& Neonatology. Volume 55, Issue 2. Pages 127-134. ISSN 1875-9572.

https://doi.org/10.1016/j.pedneo.20 13.08.005

Hecht, J. R., Bang, Y. J., Qin, S. K., Chung, H. C., Xu, J. M., Park, J. O., ... \& Slamon, D. (2016). Lapatinib in Combination With Capecitabine Plus Oxaliplatin in Human 
Epidermal Growth Factor Receptor 2-Positive Advanced or Metastatic Gastric, Esophageal, or Gastroesophageal Adenocarcinoma: TRIO-013/LOGiC--A Randomized Phase III Trial. Journal of Clinical Oncology, 34(5).

Madrigal, J. M., Ricardo, A. C., Persky, V., \& Turyk, M. (2019). Associations between blood cadmium concentration and kidney function in the US population: Impact of sex, diabetes and hypertension. Environmental research, 169, 180-188.

Mariadi, P. D., Kurniawan, I., \& Setiawan, H. (2018). Lead and cadmium mobilization from anas moscha and cairina moschata tissue using pineapple extract as chelating agents. Pollution research paper, 37(2), 330-333.

Mariadi, P. D., \& Kurniawan, I. (2019). Kandungan Logam Berat Timbal $(\mathrm{Pb})$ Dan Kadmium (Cd) Pada Daging Ikan Gabus (Channa Sriata) Yang Dijual Di Pasar KM 5 Palembang. RISET DAN INOVASI TEKNOLOGI DALAM MENGHADAPI TANTANGAN ERA REVOLUSI INDUSTRI 4.0,10(x), 900-903.

Nordberg, G.F., Fowler, B.A., and Nordberg, M. 2015. Handbook on the Toxicology of metals : Fourth edition, Volume I. general Considerations Elsevier.

Rizwan, M., Ali, S., Adrees, M., Ibrahim, M., Tsang, D. C., Zia-ur-Rehman, M., ... \& Ok, Y. S. (2017). A critical review on effects, tolerance mechanisms and management of cadmium in vegetables. Chemosphere, 182, 90105.

Permenkes. (2017). Standar Baku Mutu Kesehatan Lingkungan dan Persyaratan Kesehatan Air Untuk Higiene Sanitasi, Kolam Renang, Solus Per Aqua, dan Permandian Umum.

Soleman, S. R., Andini, S. A., \& Rosita, L. (2020). Pengaruh Paparan Timbal Terhadap Parameter Darah Tepi
Pada Orang Di Sekitar Terminal Bus Di Yogyakarta. 11-16

Suciani, S. (2007). Kadar Timbal dalam Darah Polisi Lalu Lintas dan Hubungannya dengan Kadar Hemoglobin (Studi pada Polisi Lalu Lintas yang Bertugas di Jalan Raya Kota Semarang). Tesis. Semarang: Magister Gizi Masyarakat Program Pascasarjana Universitas Diponegoro Semarang

Nübler, S., López, M. E., Castaño, A., Mol, H., Schäfer, M., Haji-AbbasZarrabi, K., ... \& Göen, T. (2021). Interlaboratory comparison investigations (ICI) and external quality assurance schemes (EQUAS) for cadmium in urine and blood: Results from the HBM4EU project. International Journal of Hygiene and Environmental Health, 234, 113711..

Vacchi-Suzzi C, Eriksen KT, Levine K, McElroy J, Tjønneland A, et al. (2015) Dietary Intake Estimates and Urinary Cadmium Levels in Danish Postmenopausal Women. PLOS ONE 10(9): e0138784. https://doi.org/10.1371/j ournal.pone.0138784

Wang, X., Cui, W., Wang, M., Liang, Y., Zhu, G., Jin, T., \& Chen, X. (2021). The association between life-time dietary cadmium intake from rice and chronic kidney disease. Ecotoxicology and environmental safety, 211, 111933. https://doi.org/10.1016/j.ecoenv.20 21.111933

. Yichen Lin, Jian Lu, Jun Wu (2021). Heavy metals pollution and health risk assessment in farmed scallops: Low level of $\mathrm{Cd}$ in coastal water could lead to high risk of seafood. Ecotoxicology and Environmental Safety. Volume 208, ISSN 01476513.

https://doi.org/10.1016/j.ecoenv.20 $\underline{20.111768}$ 